Uniwersytet im. Adama Mickiewicza, Poznań

\title{
Odrodzenie obywatela w Polsce i NRD szesnaście lat po rozpoczęciu transformacji systemowej
}

, O d roku 1989 transformację pokomunistycznej Europy określa się jako budowę społeczeństwa obywatelskiego w poszczególnych krajach, wiążącą się ściśle z odzyskiwaniem niepodległości odtwarzaniem suwerennego państwa, odbudową wspólnoty politycznej", .

Patrząc dziś z perspektywy kilkunastu lat na zmiany w Europie Środkowo-Wschodniej, za Clausem Offe można wyróżnić trzy znacznie różniące się i odbiegające od siebie schematy rozwoju wydarzeń, które doprowadziły do upadku socjalizmu²:

- w większości „krajów kontynuacji” zachowane zostały narodowa wspólnota i tym samym podstawa integracji, podczas gdy struktura polityczna i ekonomiczna została dogłębnie zreformowana;

- wraz z reorganizacją polityczno-ekonomiczną wyłoniło się, nowe” lub jak w przypadku państw bałtyckich i Słowacji, zrekonstruowane państwo narodowe;

- powołanie nowego ładu społecznego wiązało się ze zmianą systemu polityczno-ekonomicznego i wynikało ze zjednoczenia z innym państwem narodowym.

Pierwszy z wariantów typowy był dla większości krajów regionu, w tym dla Polski, wariant trzeci charakterystyczny był dla jednoczących się państw niemieckich.

Mimo, iż oba kraje, Polska i NRD, w roku 1989 odzyskały niepodległość i wyzwoliły się spod okupacji sowieckiej, tylko w odczuciu obywateli jednego z tych państw, Polski, przyniosło im to wolność. Dla większości Niemców oznaczało to tylko przejście spod jednej „okupacji” do drugiej i zastąpienie jednego ,wielkiego brata”, drugim. Jak zauważa

1 K. Murawski, Państwo i społeczeństwo obywatelskie, Kraków 1999, s. 47.

2 C. Offe, Drogi do transformacji. Doświadczenia wschodnioeuropejskie i wschodnioniemieckie, Warszawa-Kraków 1999, s. 14-15. 
Anna Wolff-Powęska: „W odróżnieniu od Polski, Węgier, Czechosłowacji, dla których odejście od realnego socjalizmu oznaczało powrót do własnej historii, narodu i wynikających zeń wartości, obywatele NRD stanęli wobec pustki tożsamości. Dylemat NRD, wyrażony został przez jedną z pisarek w niepozbawionej goryczy refleksji: Polacy mają swoją Polskę, Węgry swoje Węgry, a my mamy Niemiecką Republikę Federalną"3.

\section{Polska i Niemcy na progu transformacji}

Oprócz zasadniczej różnicy, jaką było w praktyce odzyskanie suwerenności tylko przez jeden z omawianych krajów, A. Wolff-Powęska, wskazuje jeszcze na kilka elementów, które odróżniają Polskę od NRD ${ }^{4}$ :

- Tempo transformacji. Dla Niemców ze wschodu połączenie obu państw niemieckich oznaczało przyjęcie i akceptację wzorców narzuconych przez silniejszego brata co zaowocowało utratą przez nich podmiotowości i poczucia wpływu na własne losy. Rządzący zjednoczonym już państwem niemieckim zbyt późno zorientowali się, że przeniesienie na grunt wschodni norm i wartości będzie zadaniem niezwykle trudnym i długotrwałym w porównaniu $\mathrm{z}$ adaptacją instytucji demokratycznych i gospodarki rynkowej, która przebiegła stosunkowo szybko i bezboleśnie. W Polsce, mimo, iż może wiele z reform przeprowadzonych po 1989 roku było niedoskonałych, to jednak mieszkańcy tego kraju mieli świadomość, że błędy te związane są tylko i wyłącznie z ich decyzjami. W efekcie Polacy mieli kilkanaście lat na zaakceptowanie nowych warunków życia i nauczenie się demokracji. Niemcy ze wschodu już następnego dnia po zjednoczeniu obudzili się w zupełnie innym kraju, co gorsza kraju, na którego działanie i politykę wpływ mieli bardzo ograniczony.

- Opozycja antykomunistyczna. Elementem charakterystycznym dla życia politycznego NRD był brak opozycji antykomunistycznej, która odegrała tak istotną rolę w przemianach w Polsce czy na Węgrzech. Cytowany przez Stefana Wolle'a, Reinhard Schult, jeden z protagonistów ruchu opozycyjnego w NRD, charakteryzuje atmosferę panującą w ruchu w sposób następujący: „Prawie wszyscy się znali. Nikt z nas nie miął nadziei na obalenie rządów SED. Chodziło o więcej świeżego powietrza w zatęchłej

3 A. Wolff-Powęska, Oswojona rewolucja, Poznań 1998, s. 169.

4 A. Wolff-Powęska, op. cit., s. 170-172. 
NRD, o nieco więcej swobody ruchu w kaftanie bezpieczeństwa. Byliśmy znikomą mniejszością - bez poparcia w społeczeństwie, jakie miała np. Solidarność w Polsce" ${ }^{9}$. Dobrze ilustruje to również wezwanie na transparencie niesionym podczas demonstracji w Lipsku w 1990 roku: „Helmut, weź nas za rękę i wskaż drogę do kraju cudu gospodarczego"6. W zupełnie innej sytuacji znalazła się Polska, gdzie po upadku reżimu można było wybrać nowe władze spośród byłych opozycjonistów (podobnie było zresztą w Czechosłowacji czy na Węgrzech).

- Rozbicie narodu. Czynnikiem, który bardzo negatywnie wpływał na jednoczące się Niemcy, była utrata tożsamości narodowej, zwłaszcza na wschodzie, spowodowana dramatem drugiej wojny światowej i rozliczeniami z przeszłością. Wbrew pozorom Niemcy ze Wschodu byli bardzo przywiązani do swojej socjalistycznej ojczyzny, byli dumni z sukcesów sportowych jej reprezentantów (cóż, że osiaganych często przy pomocy zakazanych środków). Całe życie konkurowali z zachodnimi rodakami, a teraz musieli się im podporządkować. Problemy związane z utratą tożsamości narodowej i swojego kraju bardzo dobrze pokazuje, nagradzany wielokrotnie film „Goodbye Lenin”. Główny bohater stara się za wszelką cenę zachować w tajemnicy przed matką, która zapadła w śpiączkę jeszcze w NRD, a obudziła się już w zjednoczonych Niemczech, zmiany które nastapiły. Jego matka jest tak przywiązana i dumna ze wszystkiego co nosi znaczek „made in DDR”, od ogórków konserwowych po I sekretarza Honeckera, iż wiadomość o upadku socjalistycznej ojczyzny mogłaby ją zabić.

- Konsekwencje wprowadzenia systemu demokratycznego i wolnego rynku. Pod tym względem obywatele dawnej NRD zostali dotknięci podwójnie. Mieszkańcy Polski, Czech czy Węgier porównywali swoją biedę, swoje problemy do współmieszkańców. Niemcy ze wschodu musieli porównywać się i cały czas byli porównywani z „lepszymi” Niemcami z zachodu ${ }^{7}$.

5 Zob. S. Wolle, Wspaniaty świat dyktatury, Warszawa 2003, s. 386; zob. także tekst J. Sułka, w: Niemcy współczesne, pod red. K. A. Wojtaszczyka, Warszawa 1999, w którym porównuje on m.in. proces transformacji w Polsce i NRD pod kątem zaangażowania społeczeństwa.

6 A. Wolff-Powęska, op. cit., s. 171.

7 Analizę uwarunkowań rozwoju społeczeństwa obywatelskiego w Polsce i NRD przeprowadził również H. Fehr w art. Aufbau der zivilen Gesellschaft, w: Przemiany w Polsce i NRD po 1989 r., pod red. J. Holzera, J. Fiszera, Warszawa 1996, s. 17-35; zob. także tekst J. Holzera w tej samej pracy. 


\section{Przebieg procesu reform}

Można wskazać na kilka czynników, które bezpośrednio wpłynęły na przebieg transformacji w Polsce i NRD. Jednym z najważniejszych był bardzo wysoki poziom opieki społecznej i rozwój państwa opiekuńczego na wschodzie Niemiec. Kraj ten traktowany był przez ZSRR jako jedna z najważniejszych figur na froncie walki o wyższość socjalizmu nad kapitalizmem, stąd specjalne przywileje gospodarcze i pieniądze, które płynęły tam od towarzyszy z całej Europy Wschodniej. To wszystko sprawiało, iż życie mieszkańca NRD było dużo łatwiejsze niż w Polsce, a my sami wjeżdżając do tego kraju czuliśmy się już niemalże jak na zachodzie. S. Wolle, charakteryzując życie w NRD, pisze: „wbrew różnym drobnym codziennym kłopotom ludzie zupełnie nieźle się urządzili, pozostawiając krytykę i sprzeciw niektórym prominentom małym grupom, które ze swej strony chciały nie tyle likwidować, ile poprawiać NRD i socjalizm"8. Dyktatura panująca w NRD była, posługując się określeniem Güntera Grassa, „wygodną dyktaturą".

Elementem, który w bezpośredni sposób wpłynął na przebieg transformacji były masowe wyjazdy obywateli zarówno ze wschodnich Niemiec, jak i z Polski. Jak podaje A. Wolff-Powęska w latach 1950-1989 do RFN wyemigrowało prawie 5 mln Niemców ze wschodu (głównie ludzi młodych). Mimo, iż ubytek ten nie był w przypadku Polski aż tak duży, to jednak w obu przypadkach najczęściej wyjeżdżali ludzie dobrze wykształceni. W efekcie zarówno w Polsce, jak i NRD brakowało elit, które mogłyby przyczynić się do odzyskania i odbudowania przez te społeczeństwa ich obywatelskiego charakteru. W przypadku wschodnich Niemiec emigracja ta była poparta niespotykaną w żadnym z innych krajów socjalistycznych indoktrynacją i inwigilacją społeczeństwa ${ }^{9}$. Dlatego upadek tak misternie skonstruowanego mechanizmu był dla tworzących go ludzi szczególnie bolesny. Jak wskazuje A. Wolff-Powęska: „Gwałtowny upadek NRD wraz z całym światem reprezentowanym przez państwo wschodnioniemieckie ideałów i wartości spowodował duchową próżnię. Obywatele tego kraju pozbawieni niemal z dnia na dzień opieki państwa, gwarantowanej dotąd przez wprawdzie niesprawiedliwy, dający jednak poczucie bezpieczeństwa system usiłują, tę próżnię wypełnić zastępczymi treściami"10.

${ }^{8}$ S. Wolle, op. cit., s. 327.

9 Dokładny opis tego procesu znaleźć można u S. Wolle’a, op. cit., od s. 10.

10 A. Wolff-Powęska, op. cit., s. 177-178. 
Prowadzi to wprost do mitologizowania przeszłości (stąd popularność sklepów sprzedających produkty z epoki czy filmów przypominających czasy NRD), znajduje także potwierdzenie w wynikach badań opinii społecznej. Według badań przeprowadzonych przez Centrum Badań Społecznych Berlina i Brandenburgii, w 1999 r. zaledwie 20\% Niemców wschodnich stwierdziło, że czuje się obywatelami zjednoczonych Niemiec. Z kolei analizy przeprowadzone pod kierunkiem Ingrid Hauschild wskazują, że 33\% Niemców ze wschodu postrzega siebie jako ofiary zjednoczenia i oczekuje troski ze strony państwa, są również sfrustrowani i zdezorientowani sytuacją, $\mathrm{w}$ jakiej się znaleźli ${ }^{11}$. Z takim zjawiskiem mamy do czynienia również w Polsce, gdzie nadal dużym szacunkiem społecznym cieszy się Edward Gierek, a niektóre władze samorządowe i mieszkańcy mają w planach stawianie mu pomników. Świadczą o tym również wyniki badań, w których wciąż duża grupa Polaków bardzo pozytywnie postrzega czasy PRL i nie jest zadowolona $\mathrm{z}$ wyników zachodzących przemian $^{12}$.

Praktyczne pozbawienie społeczeństwa opozycji i elit, które mogłyby przejąć władzę po zjednoczeniu Niemiec, doprowadziło do stanu, iż jedyną rdzennie wschodnioniemiecką partią pozostała Partia Demokratycznego Socjalizmu, sukcesorka działającej wcześniej SED. Mimo że również w Polsce kilka ugrupowań politycznych miało i ma socjalistyczne korzenie to jednak, zwłaszcza w pierwszym okresie transformacji, obywatele oddali władzę dawnym opozycjonistom. Tymczasem w pierwszym pozjednoczeniowym rządzie niemieckim tylko trzy teki ministerialne (na 19) przypadły politykom ze wschodu. „Taki układ stanowisk i podziału władzy sprawił, iż społeczność enerdowska nie czuła się współtwórcą transformacji. Tylko $10 \%$ mieszkańców NRD oceniło na początku lat 90-tych swój status jako obywateli współkształtujących nowy porządek zjednoczonego państwa. Pozostali ocenili swoją rolę jako statystów, pozbawionych wpływu na bieg wydarzeń"13. W Polsce, przynajmniej w początkowym okresie transformacji, akceptacja dla przemian i dla nowych

11 Zob. w: J. Trenkner, Naród z przeszłościq. Eseje o Niemczech, Poznań 2004, s. 116 .

${ }_{12}$ Zob. komunikaty z badań CBOS: Spoleczny odbiór zmian zachodzacych w Polsce po 1989 r., Warszawa 1996; Kiedy nam się lepiej żyto - w PRL czy III RP. Bilans zysków $i$ strat, Warszawa 1997; Kto wolatby żyć w PRL, Warszawa 2000. Według tych ostatnich badań tylko co czwarty Polak nie ma wątpliwości, że chciałby żyć w obecnej Polsce.

13 A. Wolff-Powęska, op. cit., s. 200. 
władz była zdecydowanie wyższa. Wynikało to m.in. z różnie pojmowanej w obu krajach roli państwa i społeczeństwa w procesach transformacji. W Polsce władze państwowe po 1989 roku przygotowywały i prowadziły mniej lub bardziej udane reformy gospodarcze i społeczne, jednak cały czas działo się to przy stosunkowo dużym zaangażowaniu społeczeństwa w procesie transformacji. Poniekąd, jak wskazuje, Jerzy Sułek, mogło to wynikać z faktu, iż w przeciwieństwie do RFN - materialne koszty transformacji musiało ponosić nie państwo, a właśnie społeczeństwo. W przypadku Niemiec było odwrotnie, stąd niskie zaangażowanie obywateli $\mathrm{w}$ proces przemian ${ }^{14}$.

Jednak obecnie, piętnaście lat od początku transformacji w obu krajach, ocena nie wypada już tak jednoznacznie ${ }^{15}$. Mimo że jeszcze kilka lat temu Claus Offe przekonywał, iż: „nawet po całkowitej integracji i wyrównaniu poziomu gospodarczego (co będzie zadaniem na całe pokolenia) taki ujednolicony ład gospodarczy może nie okazać się dostatecznie mocną podstawą zjednoczenia społeczeństwa niemieckiego" "16. Tylko czy dziś nadal możemy mówić o zjednoczeniu obu państw niemieckich, czy raczej o wchłonięciu słabszego przez silniejszego. Wielu Niemców, którzy pozostali na wschodzie, przez ostatnie kilkanaście lat nauczyło się pracować i prowadzić biznes tak, jak ich rodacy z zachodu. Wprawdzie nadal pozostaje tam duża grupa niezadowolonych, a radykalne ruchy polityczne znajdują zwolenników ${ }^{17}$ to jednak różnice między starymi, a nowymi landami powoli się zacierają. Jak pisze Wojciech Łukowski, mimo

14 Zob. J. Sułek, w Niemcy współczesne..., op. cit., s. 140 i dalsze.

15 Wszelkie oceny są tu mocno utrudnione ze względu na migrację ludności i wyludnianie się wschodnich landów.

16 C. Offe, op. cit., s. 16-17.

17 W ostatnich wyborach do Landatgów Saksonii i Brandenburgii w roku 2004 dwie skrajne partie - DVU oraz NPD uzyskały bardzo dobre wyniki, podobnie jak wykorzystująca nastroje nostalgii za dawnymi czasami, postkomunistyczna partia PDS. I tak w Brandenburgii PDS uzyskała drugie miejsce, zdobywając 28\% (wzrost poparcia o 8\%), DVU (Niemiecka Unia Ludowa) 6,1\%. W wyborach w Saksonii PDS z 23,6\% znalazło się na drugim miejscu, zaś NPD zdobyła 9,2\% głosów (wzrost poparcia aż o 7,8\%). W początkach lat 90 -tych odnotowano także, głównie w dawnych landach wschodnich, napady na azylantów i obcokrajowców. Według badań z roku 1990, przedstawionych przez V. Grotowicza, w książce Terroryzm w Europie Zachodniej, co piąty badany młody Niemiec był przeciwny mieszaniu się ras, a $13 \%$ poparłoby likwidacje ,zdegenerowanych istot”. Zdaniem 40\% cudzoziemcy przeszkadzają, co czwarty chętnie by się ich pozbył z kraju, a co piąty osobiście wziąłby w takiej akcji udział. 
oczywistych różnic występujących w mentalności, kulturach politycznych między „starymi”, a „nowymi” Niemcami, wpływ „tego samego systemu instytucjonalnego i systemu gospodarki rynkowej jest na tyle duży, że wymusza niejako proces tworzenia się struktury społecznej podobnej do tej, która występuje w starych landach, zaś występujące różnice będą miały jedynie charakter różnic regionalnych ${ }^{18}$. Wszystko wskazuje więc, iż już za kilka lat trudno będzie wyodrębnić grupę „Ossis” jako spadkobierców NRD. Obrazują to również wyniki badań opinii społecznej prowadzonych w Polsce i Niemczech ${ }^{19}$. Mimo, iż nadal (w 2001 roku) w obu częściach RFN wyniki były nieco różne, to jednak widać, jak wiele udało się Niemcom przez ten czas zrobić i jak skutecznie nowa demokracja rozwija się na wschodzie. Demokracja jest najlepszą formą rządów dla $88 \%$ mieszkańców zachodnich landów, 69\% mieszkańców wschodnich landów i tylko 53\% Polaków.

\section{Preferowana forma rządów w Polsce i Niemezech}

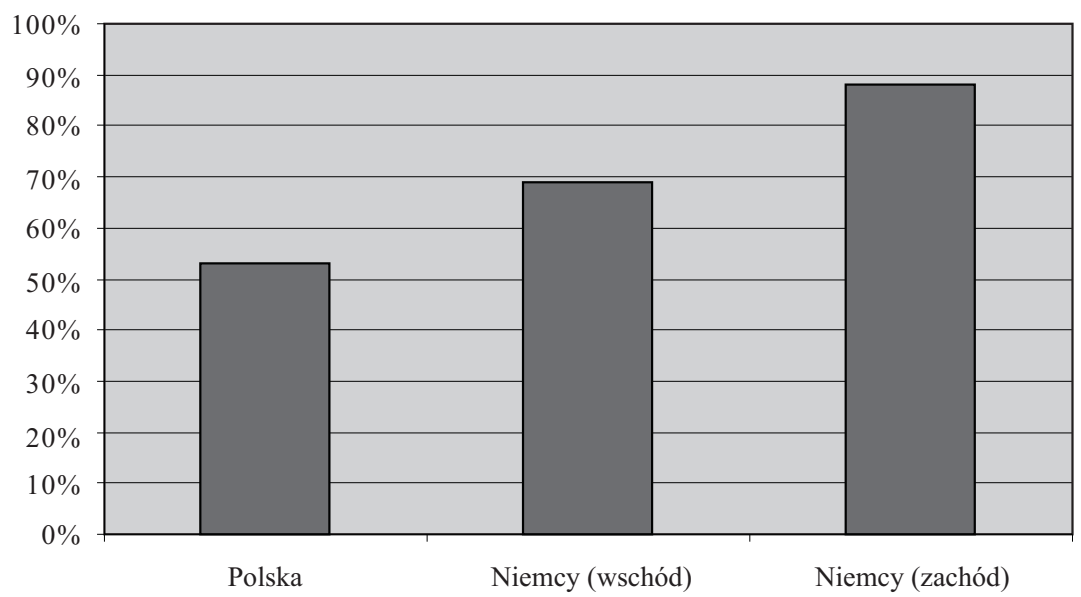

$\square \quad$ Demokracja jest najlepszą formą rządów

Źródło: Na podstawie sondażu CBOS, Postawy wobec wolnego rynku i demokracji w Polsce $i$ w Niemczech, 2001.

18 W. Łukowski, w: Niemcy współczesne..., op. cit., s. 211.

19 Na podstawie Komunikatu z badań CBOS, Postawy wobec wolnego rynku i demokracji $w$ Polsce $i w$ Niemczech, 2001. 
Można powiedzieć, że przeszczepienie ustroju demokratycznego i jego instytucji było najprostsze, a rozwój świadomości społecznej cały czas pozostaje w tyle, jednak bez stworzenia ram instytucjonalnych odrodzenie społeczeństwa obywatelskiego byłoby na wschodzie niemożliwe. Podobnie układają się proporcje w odpowiedzi na pytanie: „Czy jest Pan(i) zadowolony(a) ze sposobu, w jaki funkcjonuje obecnie demokracja w kraju". $\mathrm{Na}$ zachodzie Niemiec odpowiedzi tak udzieliło 53\% badanych, na wschodzie 27\%, w Polsce tylko 8\% pytanych osób. Można się domyślać, że dziś zarówno w Polsce, jak i w Niemczech wskaźniki te byłyby niższe, jednak proporcje pomiędzy krajami zostałyby zachowane.

W analogiczny sposób badani odpowiadali na pytanie o zadowolenie $\mathrm{z}$ funkcjonowania gospodarki wolnorynkowej w opisywanych krajach. Mimo utrzymującego się stale wysokiego poziomu bezrobocia na wschodzie Niemiec miliardy euro, które zostały „wpompowane” w gospodarkę nowych landów, a także wysoki poziom zabezpieczeń socjalnych powoduje, że „nowi” Niemcy znacznie przychylniej od Polaków oceniają postępujące zmiany gospodarcze. Na pytanie: „Czy powstanie/rozwój gospodarki wolnorynkowej jest korzystne czy niekorzystne dla przyszłości kraju", w sposób twierdzący odpowiedziało 79\% Niemców z zachodu, $55 \%$ na wschodzie i 38\% Polaków.

\section{Preferowana forma ustroju gospodarczego w Polsce i Niemczech}

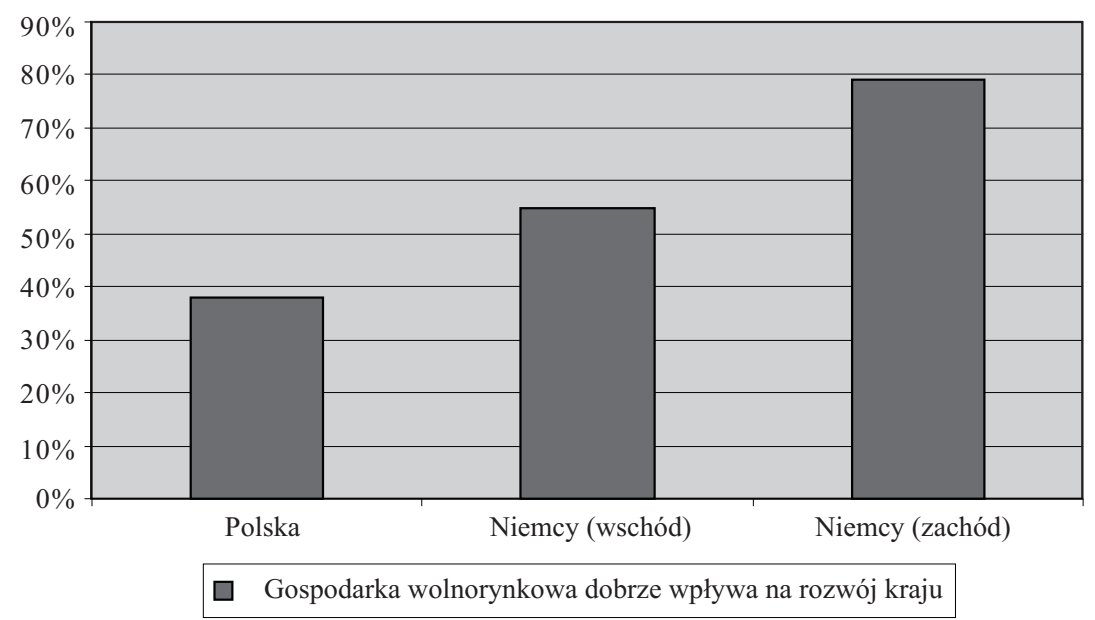

Źródło: Na podstawie sondażu CBOS, Postawy wobec wolnego rynku i demokracji w Polsce i w Niemczech, 2001. 
Porównując całość wyników prezentowanych przez CBOS (zwłaszcza dotyczących Polski i byłej NRD) można zauważyć, że mieszkańcy wschodnich Niemiec silniej niż Polacy akceptują nowy porządek polityczny i gospodarczy, są bardziej zadowoleni zarówno z funkcjonowania demokracji, jak i gospodarki rynkowej. Jednocześnie, co ważne, widać stopniowe zbliżanie się poglądów, opinii w obu częściach Niemiec, przy stale narastającym niezadowoleniu $\mathrm{z}$ działalności nowego ustroju w Polsce.

\section{Czy przetrwa NRD?}

Choć jeszcze kilka lat temu wydawało się to nierealne, można dziś założyć, iż w ciągu najbliższych kilkunastu lata nastąpi zatarcie różnic między starymi i nowymi landami. Jest i będzie to związane ze stałym rozwojem gospodarczym tej części kraju (dzięki wielkim dotacjom z kasy federalnej i Unii Europejskiej), a także wymianą obywateli między starymi i nowymi landami. Mimo dużych trudności i niedocenienia u progu transformacji różnic mentalnych i świadomościowych, z czasem pamięć i tęsknota za socjalistyczną ojczyzną będzie zanikać. Tym bardziej, że już w czasach NRD pojęcie narodu, w sensie posiadania własnej zbiorowej świadomości i tożsamości narodowej, było kategorią bardzo mglistą ${ }^{20}$, a jedność społeczeństwa wynikała głównie z indoktrynacji i inwigilacji (choć w efekcie sprzyjało to wytworzeniu się u niektórych obywateli rzeczywistych więzi z ludową ojczyzną). Wspomniana powierzchowność tych związków powinna również sprzyjać przyjęciu zachodnich wzorców.

Potwierdzają to wyniki przytoczonych badań, gdzie akceptacja dla demokracji i wolnego rynku wśród Niemców ze wschodu jest dużo wyższa od wskaźników notowanych w Polsce. Także poziom „obywatelskości” mierzony aktywnością wyborczą jest w nowych landach dużo wyższy niż w Polsce. Lata afer i niekompetencji w polskiej polityce przyczyniły się do wielkiego rozczarowania Polaków demokracją i przemianami. Jeśli przyjmiemy, że w pojęciu społeczeństwa obywatelskiego łączą się dwie polityczne koncepcje wartości: idea obywatela wywodząca się z tradycji Rewolucji Francuskiej oraz koncepcja samoorganizującej się wspólnoty społecznej i politycznej, społeczeństwo obywatelskie rozumiane będzie

20 C. Offe, op. cit., s. 28. 
jako świadomy swego znaczenia podmiot pozostający w relacji do państwa. W pojęciu tym przejawia się zatem myśl przewodnia samoorganizacji, działania na rzecz wspólnoty politycznej i społecznej, obywatelskiego zaangażowania, jak również wzajemnej akceptacji politycznej działających na tym polu podmiotów. Zaangażowanie w ramach społeczeństwa obywatelskiego oznacza aktywne uczestnictwo w podejmowaniu i realizacji zadań, a reprezentacja uzupełniona zostaje przez partycypację. Takie zdefiniowanie pojęcia społeczeństwa obywatelskiego sprawia, iż jeszcze silniej widoczne jest zróżnicowanie postaw Polaków i Niemców. Dzieje się tak choć, jak piszą analizujący wyniki European Values Studies Jerzy Bartkowiak i Aleksandra Jasińska-Kania: „Zjednoczenie Niemiec także spowodowało obniżenie aktywności społecznej i to w obu częściach wschodniej i zachodniej, mimo że struktura instytucjonalna RFN nie została naruszona. W części wschodniej przyczyny drastycznego spadku przynależności do związków zawodowych, partii i organizacji sportowych, które w NRD były wymuszane naciskiem politycznym, są oczywiste. Trudniejszy do wyjaśnienia jest podobny, choć słabszy kierunek zmian w zachodniej części Niemiec, gdzie społeczeństwo obywatelskie także boryka się z kłopotami przystosowania się do przekształceń struktu-

\section{Członkostwo i aktywność w organizacjach dobrowolnych w Polsce i Niemczech}

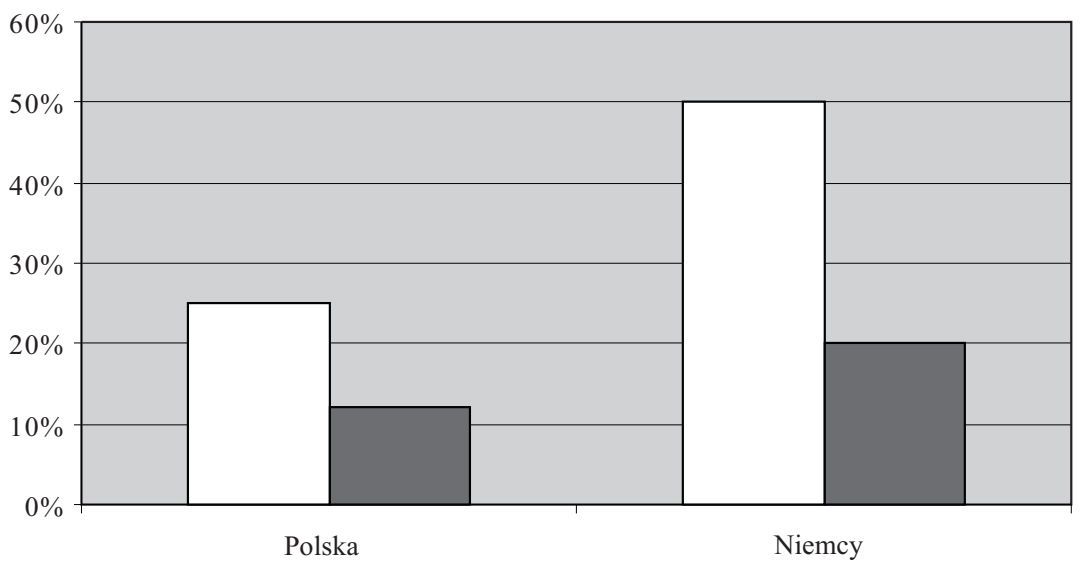

Członkostwo Aktywność

Źródło: Na podstawie European Values Study, w: Polacy wśród Europejczyków, red. A. Jasińska-Kania, M. Marody, Warszawa 2002. 
ralnych kraju"21. Wyniki badań EVS, prowadzonych w latach 1999-2000 w 26 krajach, pokazują że zarówno członkostwo, jak i aktywność w organizacjach dobrowolnych jest w Niemczech dwukrotnie wyższa niż w Polsce.

W badaniach nie uwzględniono podziału na część wschodnią i zachodnią. Wydaje się on jednak pośrednio widoczny w porównaniu Niemiec $\mathrm{z}$ innymi rozwiniętymi demokracjami europejskimi. Zestawienie to pokazuje, iż zarówno kategoria członkostwa, jak i aktywności pozostają na poziomie o wiele niższym od sąsiadów Niemiec. Jest to szczególnie widoczne właśnie w przypadku aktywności, która spośród piętnastu krajów tworzących do niedawna Unię Europejską jest niższa tylko w Hiszpanii i Portugalii.

\section{Wnioski}

Choć Polacy mogli przez lata szczycić się własną nie narzuconą z zewnątrz drogą przemian, to jednak paradoksalnie dzisiaj Niemcy ze wschodu lepiej oceniają swój „nowy” kraj i panujący w nim system „społeczno-polityczny”. Na ile jest to wynikiem pieniędzy płynących z zachodu do byłej NRD, zaś kryzys obywatelstwa w Polsce, działaniem rodzimych polityków i zbyt wolno w odczuciu społecznym poprawiającej się sytuacji gospodarczej mieszkańców, pozostaje kwestią otwartą. Przedstawiciele polskiego sektora pozarządowego często podkreślają, że ustrój społeczny i polityczny jest skrajnie scentralizowany, a władze otwieraja się na obywateli tylko wtedy, jeżeli są bezradne w jakiejś dziedzinie. Natomiast tam, gdzie wydaje jej się, że działa skutecznie, nie chce uznać pierwszeństwa czy chociażby partnerstwa inicjatyw obywatelskich. Jednak wydaje się, iż to właśnie w Polakach zachowały się ukryte pokłady aktywności obywatelskiej, które ujawniają się w sytuacjach trudnych, kryzysowych $^{22}$.

Jeśli za miarę rozwoju społeczeństwa obywatelskiego uznamy udział w życiu politycznym i zaangażowanie w działalność organizacji pozarządowych, to można powiedzieć, że Niemcy ze wschodu lepiej od Po-

21 J. Bartkowiak, A. Jasińska-Kania, Organizacje dobrowolne, a rozwój społeczeństwa obywatelskiego, w: Polacy wśród Europejczyków, pod red. A. Jasińska-Kania, M. Marody, Warszawa 2002, s. 77.

22 Więcej: http://www.ngo.pl/labeo/app/cms/x/85419;jsessionid=55D8E357F44 D155E22E7E5A170399035, z 10.04.2005. 
laków przystosowali się do życia w nowej rzeczywistości. Jeśli jednak weźmiemy pod uwagę potencjał drzemiący w obu narodach, to Polacy mają cały czas szansę na zbudowanie sprawnego, a przede wszystkim własnego, nowoczesnego społeczeństwa. Atut zachowania w procesie reform własnego kraju, na który to kraj Polacy tak często narzekają, może okazać się decydujący. Niemcy ze wschodu na taki przywilej liczyć nie mogli.

\section{Summary}

In the Author's opinion, if the development of civic society is to be measured in terms of participation in political life and involvement in non-government organizations East Germans seem to have adapted to the new reality better than Poles. However, if we take into consideration the potential of both nations Poles still stand a chance to build an efficient, and, first of all, their own, modern society. The advantage of having retained their own country, although so often criticized by Poles, may turn out to be fundamental. East Germans could not enjoy this privilege. 